Issue 3 (November, 2017)

\title{
Implementasi Komitmen Organisasional Terhadap Kepuasan Kerja Pegawai
}

\author{
Indriyani Tahir ${ }^{1)}$, Herman Sjaharuddin²), Hj. Heslina ${ }^{3)}$ \\ indriyanitahiras12@gmail.com \\ 1) Mahasiswa Program Studi Manajemen pada Sekolah Tinggi Ilmu Ekonomi Bongaya \\ Makassar \\ 2,3) Dosen Program Studi Manajemen pada Sekolah Tinggi Ilmu Ekonomi Bongaya \\ Makassar
}

\begin{abstract}
ABSTRAK
Penelitian ini bertujuan untuk menguji dan menganalisis implementasi Komitmen Organisasional Terhadap Kepuasan Kerja Pegawai Perusahaan Daerah Air Minum Kota Makassar. Populasi dalam penelitian ini sejumlah 149 Pegawai. Penarikan sampel dilakukan dengan menggunakan stratified random sampling sehingga diperoleh jumlah sampel sebanyak 60 Pegawai, namun terdapat 2 (dua) di antaranya yang outliers (cacat) sehingga keseluruhan yang digunakan hanya 58 data yang dapat dianalisis dengan menggunakan WarpPLS Ver. 5,0. Hasil penelitian menunjukkan bahwa variabel Komitmen Organisasional pada dimensi komitmen berkelanjutan dan komitmen normative yang rendah dan ditunjukkan pegawai terbukti dapat meningkatkan kepuasan kerja, sementara komitmen afektif yang tinggi dalam pelaksanaannya terbukti belum mampu meningkatkan Kepuasan kerja pegawai di perusahaan daerah air minum Kota Makassar.
\end{abstract}

Kata kunci $\quad$ : Komitmen organisasional, kepuasan kerja

\section{ABSTRACT}

This study aims to determine the Implementation of Organizational Commitment on Job Satisfaction Employee on Makassar Regional Water Company. The populations in this study a number of 149 Employees. Sampling was done by using stratified random sampling in order to obtain the number of samples amounted 60 Employee, but there are 2 (two) of them were outliers (disabled) so that the overall use only 58 data that can be analyzed using WarpPLS Ver. 5.0. The results showed that the variables of Organizational Commitment on the dimensions of the continuance commitment and normative commitment is low and demonstrated proven to improve employee job satisfaction, while a high of affective commitment in practice proved not able to improve employee job satisfaction on Makassar Regional Water Company.

Keywords: Organizational commitment, Job Satisfaction

\section{Latar Belakang}

Perusahaan Daerah Air Minum (PDAM) Kota Makassar sebagai salah satu unit usaha strategis milik pemerintah daerah yang berorientasi pada pelayanan umum (public service), dituntut untuk dapat memberikan pelayanan yang berkualitas. Namun pada kenyataannya Perusahaan Daerah Air Minum (PDAM) Kota 


\section{JURNAL ORGANISASI DAN MANAJEMEN}

Issue 3 (November, 2017)

Makassar sering mendapat keluhan dari masyarakat atau pelanggannya. (Pamungkas dan Raharjo,2014).

Sebagai salah satu perusahaan milik daerah, tujuan utama perusahaan adalah untuk meningkatkan pelayanan kepada masyarakat, maka analisis terhadap kepuasan kerja pegawai pada organisasi, sangat penting. Hal ini dimaksudkan untuk mengetahui faktor penyebab tinggi ataupun rendahnya kepuasan kerja seorang pegawai. Kepuasan kerja (job satisfaction) adalah keadaan emosional yang menyenangkan atau tidak menyenangkan atas suatu pekerjaan. Kepuasan kerja merupakan evaluasi yang mengambarkan seseorang atas perasaan sikapnya senang atau tidak senang, puas atau tidak puas dalam bekerja (Handoko,2006:212, dalam Trikardilla, dkk, 2016;Rivai,2010:856, dalam Anas, 2013). Faktor-faktor yang mempengaruhi tinggi rendahnya kepuasan kerja pegawai dalam bekerja adalah: Gaji,Pekerjaan itu sendiri, Promosi, Sikap atasan, dan rekan kerja (Robbins, 2007 dalam Rimata Ega Praja, 2014). Pendekatan teori yang digunakan dalam menganalisis kepuasan kerja pada penelitian ini menggunakan teori X dan Y yang dikemukakan Douglas Mc.Gregor dalam Hasibuan (2008:160), teori pemeliharaan atau dua faktor $\mathrm{X}$ adalah teori yang menjelaskan penyebab individu merasakan kepuasan dalam bekerja (faktor motivasi), sedangkan faktor Y menjelaskan faktor penyebab terjadinya ketidak puasan yang dirasakan individu dalam bekerja.

Perwujudan dari kepuasan yang dirasakan individu dalam bekerja dapat diperlihatkan melalui komitmen organisasional pegawai. Komitmen organisasional (organizational commitment) merupakan tingkat keyakinan pegawai untuk menerima tujuan organisasi sehingga berkeinginan untuk tetap tinggal dan menjadi bagian dari organisasi tersebut. Komitmen organisasi merupakan sikap yang di definisikan sebagai keinginan kuat untuk tetap sebagai anggota organisasi tertentu, keinginan untuk berusaha keras sesuai keinginan organisasi, keyakinan tertentu dan penerimaan nilai dan tujuan organisasi. Dengan (Sopiah, 2008 dalam Setiawan, H. 2009; Luthans, 2005 dalam Noor,Z.A, 2012 ).

Komitmen organisasional digolongkan menjadi tiga kompenen model yaitu: Affective commitment (komitmen afektif), continuance commitment (komitmen berkelanjutan), normative commitment (komitmen normatif) Luthans, (2006) dalam Rimata Ega Praja, (2014). Penelitian terdahulu memberikan bukti bahwa komitmen organisasi yang dimensinya meliputi, komitmen afektif, komitmen berkelanjutan,dan komitmen normatif berpengaruh positif dan signifikan terhadap kepuasan kerja (Noor, Z.A, 2012; Rimata Ega Praja, 2014). Hasil temuan lain menjelaskan bahwa komitmen organisasi berpengaruh negatif dan tidak signifikan terhadap kepuasan kerja (Probo,dan Kartika, 2008)

Fakta lapangan yang diperolah pada saat dilakukanya pra-penelitian menunjukkan bahwa Masalah yang berkaitan dengan komitmen organisasional adalah kurangnya rasa ikut memiliki (sense of belonging) pegawai terhadap perusahaan. Menurut Allen dan Meyer (1996), keterlibatan pegawai dalam suatu perusahaan menunjukkan kuatnya keinginan seseorang untuk terus bekerja bagi suatu perusahaan, akan tetapi menurut informasi yang diberikan oleh salah satu pegawai Perusahaan Daerah Air Minum (PDAM) Kota Makassar, pegawai tidak dilibatkan dalam berbagai pengambilan keputusan atau kebijakan, sehingga ini menyebabkan rasa ikut memiliki (sense of belonging) pegawai terhadap organisasi menjadi rendah. 


\section{JURNAL ORGANISASI DAN MANAJEMEN}

Issue 3 (November, 2017)

\section{Tinjauan Pustaka}

1. Komitmen organisasional

Sopiah (2008) menyatakan bahwa komitmen organisasional (organizational commitment) merupakan tingkat keyakinan pegawai untuk menerima tujuan organisasi sehingga berkeinginan untuk tetap tinggal dan menjadi bagian dari organisasi tersebut. pegawai yang berkomitmen cenderung lebih bertanggungjawab dalam memberikan pelayanan (Ping et al., 2012). Berbagai studi penelitian menunjukkan bahwa orang- orang yang relatif puas dengan pekerjaannya akan lebih berkomitmen terhadap organisasi (Mathis dan Jackson, 2011). Huang dan Hsiao (2007) menyatakan adanya hubungan signifikan dan positif antara kepuasan kerja dengan komitmen organisasi. pegawai akan memiliki komitmen organisasi yang tinggi ketika merasa puas dengan pekerjaan, supervisi, gaji, promosi dan rekan kerja (Sjahruddin, H., \& Sudiro, 2013; Harrison dan Hubbard, 1998 dalam Puspitawati, 2014).

\section{Kepuasan kerja}

Kepuasan kerja adalah suatu sikap umum seorang individu terhadap pekerjaannya. Kepuasan kerja merupakan seperangkat perasaan pegawai tentang menyenangkan atau tidak menyenangkan pekerjaan mereka. (Robbins, 2001; Davis, 2002; dalam Wibowo dan Putra, 2015 ). Menurut Rivai (2004), teori tentang kepuasan kerja yang cukup dikenal yaitu teori keadilan (equity theory) mengemukakan bahwa orang merasa puas atau tidak puas, tergantung ada atau tidak keadilan (equity) dalam suatu situasi, khususnya situasi kerja, seseorang akan membandingkan rasio input hasil dirinya dengan rasio input hasil orang lain dan apabila perbandingan itu dianggap cukup adil, maka pegawai akan merasa puas.

Kepuasan kerja merupakan perasaan puas individu karena harapan sesuai dengan kenyataan yang diperoleh di tempat kerja baik dalam hal beban kerja, lingkungan atau kondisi kerja, hubungan dengan rekan kerja atau penyelia, dan kompensasi. Kepuasan kerja sulit didefinisikan karena rasa puas itu bukan keadaan yang tetap melainkan dapat dipengaruhi dan diubah oleh kekuatan-kekuatan baik dari dalam maupun dari luar lingkungan kerja (Suwatno dan Priansa, 2011). Menurut Sopiah (2008), aspek-aspek kerja yang berpengaruh terhadap kepuasan kerja adalah (a) promosi, (b) gaji, (c) pekerjaan itu sendiri, (d) supervise, (e) teman kerja, (f) keamanan kerja, (g) kondisi kerja, (h) administrasi/kebijakan perusahaan, (i) komunikasi, (j) tanggung jawab, (k) pengakuan, (l) prestasi kerja, dan (m) kesempatan untuk berkembang.

Faktor yang mempengaruhi tinggi rendahnya kepuasan kerja Menurut Tsai dan Huang (2008), meliputi;

a) Pengawasan, yaitu keberadaan seseorang yang senantiasa memberikan perintah atau petunjuk dalam pelaksanaan kerja.

b) Rekan kerja, yaitu relasi kepada siapa seseorang senantiasa berinteraksi, dalam pelaksanaan pekerjaan seseorang dapat merasakan rekan kerjanya sangat menyenangkan atau tidak menyenangkan.

c) Insentif, yaitu jumlah bayaran yang diterima seseorang sebagai akibat dari pelaksanaan kerja, apakah sesuai dengan kebutuhan yang dirasakan adil.

d) Promosi, yaitu kemungkinan seseorang dapat berkembang melalui kenaikan jabatan.

e) Pekerjaan itu sendiri. 


\section{JURNAL ORGANISASI DAN MANAJEMEN}

Issue 3 (November, 2017)

Menurut pendapat lain Robbins dan Judge (2008) menyebutkan kepuasan kerja dapat diukur dengan:
a) Kepuasan terhadap beban kerja
b) Kompensasi
c) Promosi
d) Pengawasan (supervisor)
e) dan rekan kerja

\section{Metode Penelitian}

Penelitian ini termasuk penelitian metode deskriptif kuantitatif yang bertujuan untuk menjelaskan suatu fenomena empiris yang disertai data statistic dan pola hubungan antara variabel. Penelitian ini menggunakan analisis SEM (Structural equation modeling) dibantu dengan WaphPLS Ver. 5.0 sebagai peralatan penelitian

\section{Hasil Penelitian}

\section{Evaluasi model pengukuran (outer model)}

Evaluasi outer model dilakukan melalui 3 kriteria yaitu convergent validity, discriminant validity dan composite reliability. Convergent validity dari model pengukuran dapat dilihat dari korelasi antara skorindikator dengan skor konstruknya (loading factor) dengan kriteria nilai loadingfactor dari setiap indikator lebih besar dari 0,70 dapat dikatakan valid. Selanjutnyauntuk nilai p-value apabila < 0,05 dianggap signifikan. Loading factor antara 0,40-0,70 harus tetap dipertimbangkan untuk dipertahankan. Selanjutnya dijelaskan pula bahwa, indikator dengan loading $<0,40$ dihapus dari model. Penghapusan indikatordengan loading antara 0,40-0,70 dilakukan apabila indikator tersebut dapatmeningkatkan AVE dan composite reliability diatas nilai batasannya. Nilai batasanuntuk AVE 0,50 dan composite reliability adalah 0,50 (Machfud dan Dwi, 2013: 66; dalam Ovi Arista, 2015). Hasil pengolahan Convergent Validity dapat dilihat pada tabel berikut ini: Tabel 1 Combined loadings and cross-loadings

\begin{tabular}{|l|l|l|l|l|l|l|c|}
\hline MODEL 1 & \multicolumn{1}{|c|}{ KA } & \multicolumn{1}{|c|}{ KB } & \multicolumn{1}{|c|}{ KN } & \multicolumn{1}{|c|}{ KK } & \multicolumn{1}{|c|}{ SE } & \multicolumn{1}{|c|}{ P value } & KET \\
\hline $\mathrm{X}_{11}$ & 0.715 & -0.167 & 0.023 & -0.035 & 0.102 & $<0.001$ & Terpenuhi \\
\hline $\mathrm{X}_{12}$ & 0.747 & 0.155 & 0.142 & 0.127 & 0.101 & $<0.001$ & Terpenuhi \\
\hline $\mathrm{X}_{13}$ & 0.906 & 0.004 & -0.136 & -0.077 & 0.095 & $<0.001$ & Terpenuhi \\
\hline $\mathrm{X}_{21}$ & 0.057 & 0.863 & 0.047 & 0.103 & 0.096 & $<0.001$ & Terpenuhi \\
\hline $\mathrm{X}_{22}$ & 0.034 & 0.935 & -0.162 & -0.141 & 0.094 & $<0.001$ & Terpenuhi \\
\hline $\mathrm{X}_{23}$ & -0.101 & 0.804 & 0.138 & 0.053 & 0.099 & $<0.001$ & Terpenuhi \\
\hline $\mathrm{X}_{31}$ & -0.039 & 0.227 & 0.769 & 0.008 & 0.100 & $<0.001$ & Terpenuhi \\
\hline $\mathrm{X}_{32}$ & 0.076 & -0.012 & 0.941 & -0.146 & 0.094 & $<0.001$ & Terpenuhi \\
\hline $\mathrm{X}_{33}$ & -0.048 & -0.191 & 0.854 & 0.154 & 0.097 & $<0.001$ & Terpenuhi \\
\hline $\mathrm{Y}_{11}$ & 0.028 & 0.008 & 0.04 & 0.885 & 0.096 & $<0.001$ & Terpenuhi \\
\hline $\mathrm{Y}_{12}$ & -0.105 & 0.106 & 0.09 & 0.824 & 0.098 & $<0.001$ & Terpenuhi \\
\hline $\mathrm{Y}_{13}$ & 0.038 & -0.064 & -0.184 & 0.911 & 0.095 & $<0.001$ & Terpenuhi \\
\hline $\mathrm{Y}_{14}$ & 0.018 & -0.048 & 0.026 & 0.925 & 0.094 & $<0.001$ & Terpenuhi \\
\hline
\end{tabular}

Berdasarkan hasil pengolahan data diatas maka dapat dijelaskan:

1) Convergent validity(uji validitas) untuk konstruk komitmen organisasional $\left(\mathrm{X}_{1}\right)$. Pada model diatas, hasil pengolahan data tersebut menjelaskan bahwa dari 3 dimensi komitmen organisasional yaitu komitmen afektif, yaitu $\mathrm{X}_{11}, \mathrm{X}_{12}$, danX $\mathrm{X}_{13}$,

Halaman 93

Authors : Indriyani Tahir et al. (November, 2017). 90 - 104

https://dx.doi.org/10.17605/OSF.IO/GA8WX 


\section{JURNAL ORGANISASI DAN MANAJEMEN}

Issue 3 (November, 2017)

semua indikator tersebut memenuhi standar Convergent Validitydengan nilai $>0.70$ dan $P$-value juga telah memenuhi syarat yaitu memiliki nilai sebesar $<0,001(<0,05)$ sehingga indikator-indikator tersebut tidak dikeluarkan pada model 2.

2) Convergent validity(uji validitas) untuk konstruk kinerja pegawai (Y). Pada model diatas dapat disimpulkan bahwa dari 4 indikator kepuasan kerja pegawai, yaitu $\mathrm{Y}_{11}, \mathrm{Y}_{12}, \mathrm{Y}_{13}$, dan $\mathrm{Y}_{14}$, semua indikator tersebut memenuhi standar Convergent Validity dengan nilai $>0.70$ dan P-value juga telah memenuhi syarat yaitu memiliki nilai sebesar $<0,001(<0,05)$.

Pengukuran lainnya dari convergent validity adalah dengan melihat nilai AVE (Average Variance Extracted). Menurut pendapat (Mahfud Sholihin dan Dwi Ratmono (2013: 73), dalam Arista, 2015) menyatakan bahwa AVE (Average Variance Extracted) juga digunakan untuk evaluasi validitas konvergen, kriteria yang harus dipenuhi yaitu nilai AVE $>0,50$.

2. Uji Composite Reliability

Suatu variabel yang dipandang mampu (handal) dalam menjelaskan data dari variabel tersebut, pengujiannya dapat dilihat pada nilai composite reliabilitydan Cronbach's Alpha $<0,60$, untuk itu dapat diperlihatkan pada tabel berikut:

Tabel 2. Hasil output latent variable coefficients

\begin{tabular}{|l|c|c|c|c|}
\hline & KA & KB & KN & KK \\
\hline R-squared & & & & 0.269 \\
\hline Adj.R-squared & & & & 0.228 \\
\hline Composite Reliab. & 0.835 & 0.902 & 0.892 & 0.937 \\
\hline Cronbach's Alpha & 0.699 & 0.836 & 0.816 & 0.909 \\
\hline Avg.Var.Extrac & 0.630 & 0.755 & 0.735 & 0.787 \\
\hline Full Collin.VIF & 1.149 & 1.077 & 1.298 & 1.292 \\
\hline$Q$-squared & & & & 0.263 \\
\hline
\end{tabular}

Nilai composite reliability untuk variabel komitmen organisasional yang terdiri dari komitmen afektif sebesar $0.835>0,60$ sedangkan untuk variabel dimensi komitmen berkelanjutan sebesar 0.902>0,60,sedangkan untuk variabel dimensi komitmen normatif sebesar $0.892>0,60$, dan yang terakhir pada variabel kepuasan kerja pegawai sebesar 0.937>0,60. Selanjutnya untuk Cronbach's Alpha pada variabel komitmen organisasional yang terdiri dari komitmen afektif sebesar 0.699> 0,60 , sedangkan untuk variabel dimensi komitmen berkelanjutan sebesar 0.836> 0,60,sedangkan untuk dimesi komitmen normatif sebesar $0.816>0,60$ dan yang terakhir pada variabel kepuasan kerja pegawai sebesar 0.909>0,60. Untuk nilai Average Variances Extracted (AVE)/ nilai variasi rata-rata pada dimensi komitmen organisasional yang terdiri dari komitmen afektif sebesar $0.630>0,50$ sedangkan untuk dimensi komitmen berkelanjutan sebesar $0.755<0,50$, sedangkan untuk dimensi komitmen normatif sebesar $0.735<0,50$ dan yang terakhir pada variabel kepuasan kerja pegawai sebesar $0.787>0,50$. 


\section{JURNAL ORGANISASI DAN MANAJEMEN}

Issue 3 (November, 2017)

Berdasarkan hasil tersebut maka keseluruhan nilai memenuhi kriteria pengujian, sehingga terdapat cukup alasan yang kuat untuk melanjutkannya pada pengujian berikutnya.

Tabel 3. Nilai AVE (Average Variance Extracted)

\begin{tabular}{|c|c|c|c|}
\hline Variabel Laten & Nilai AVE & Kriteria & Keterangan \\
\hline KA & 0.630 & $>0,50$ & Terpenuhi \\
\hline KB & 0.755 & $>0,50$ & Terpenuhi \\
\hline KN & 0.735 & $>0,50$ & Terpenuhi \\
\hline KK & 0.787 & $<0,50$ & Terpenuhi \\
\hline
\end{tabular}

Berdasarkan hasil tersebut ketiga konstruk telah memenuhi convergent validity. Komitmen organisasional yang terdiri dari dimensi komitmen afektif dengan nilai $0.630>0,50$, dimensikomitmen berkelanjutan dengan nilai $0.755>0,50$,dan dimensi komitmen normatif dengan nilai juga telah memenuhi nilai 0.735> 0,50 dan kepuasan kerja pegawai memiliki nilai 0.787> 0,50. Kesimpulannyakeseluruhan variabel memenuhi kriteria convergent validity.

\section{Dicriminant Validity}

Discriminant validity dinilai dari cross loading pengukuran dengan konstruk. Dapat dilihat dengan melihat loading konstruk laten, yang akan memprediksi indikatornya lebih baik daripada konstruk lainnya. Jika korelasi konstruk dengan pokok pengukuran (setiap indikator) lebih besar daripada ukuran konstruk lainnya maka validitas diskriminan terpenuhi.

Tabel 3. Validitas diskriminan

\begin{tabular}{|c|c|c|c|c|c|c|c|}
\hline \multirow{2}{*}{ Indikator } & \multirow{2}{*}{ Loading } & & \multicolumn{4}{|c|}{ Nilai Loading ke konstruk lainnya } & \multirow{2}{*}{ Keterangan } \\
\cline { 5 - 7 } & & KA & KB & KN & KK & \\
\hline $\mathrm{X}_{11}$ & 0.715 & $>$ & & -0.167 & 0.023 & -0.035 & Terpenuhi \\
\hline $\mathrm{X}_{12}$ & 0.747 & $>$ & & 0.155 & 0.142 & 0.127 & Terpenuhi \\
\hline $\mathrm{X}_{13}$ & 0.906 & $>$ & & 0.004 & -0.136 & -0.077 & Terpenuhi \\
\hline $\mathrm{X}_{21}$ & 0.863 & $>$ & 0.057 & & 0.047 & 0.103 & Terpenuhi \\
\hline $\mathrm{X}_{22}$ & 0.935 & $>$ & 0.034 & & -0.162 & -0.141 & Terpenuhi \\
\hline $\mathrm{X}_{23}$ & 0.804 & $>$ & -0.101 & & 0.138 & 0.053 & Terpenuhi \\
\hline $\mathrm{X}_{31}$ & 0.769 & $>$ & -0.039 & 0.227 & & 0.008 & Terpenuhi \\
\hline $\mathrm{X}_{32}$ & 0.941 & $>$ & 0.076 & -0.012 & & -0.146 & Terpenuhi \\
\hline $\mathrm{X}_{33}$ & 0.854 & $>$ & -0.048 & -0.191 & & 0.154 & Terpenuhi \\
\hline $\mathrm{Y}_{11}$ & 0.885 & $>$ & 0.028 & 0.008 & 0.04 & & Terpenuhi \\
\hline $\mathrm{Y}_{12}$ & 0.824 & $>$ & -0.105 & 0.106 & 0.09 & & Terpenuhi \\
\hline $\mathrm{Y}_{13}$ & 0.911 & $>$ & 0.038 & -0.064 & -0.184 & & Terpenuhi \\
\hline $\mathrm{Y}_{14}$ & 0.925 & $>$ & 0.018 & -0.048 & 0.026 & & Terpenuhi \\
\hline
\end{tabular}

Berdasarkan data di atas, keseluruhan indikator telah memenuhi kriteria validitas diskriminan. Dimensi komitmen avektif yang memiliki 3 pernyataan yang

Authors : Indriyani Tahir et al. (November, 2017). 90 - 104

Halaman 95

https://dx.doi.org/10.17605/OSF.IO/GA8WX 
Issue 3 (November, 2017)

dilambangkan dengan $\mathrm{X}_{11}, \mathrm{X}_{12}$, dan $\mathrm{X}_{13}$. Untuk pernyataan $\mathrm{X}_{11}$ memiliki nilai loading 0.715 yang nilai loading-nya lebih besar dari loading ke konstruk lain yaitu -0.167 , 0.023 dan -0,035 dan ke 2 pernyataan dari dimensi komitmen avektif lainnya juga memiliki nilai loading yang lebih besar dari nilai loading ke konstruk lain.

Dimensi komitmen berkelanjutan yang memiliki 3 pernyataan yang dilambangkan dengan $\mathrm{X}_{21}, \mathrm{X}_{22}$, dan $\mathrm{X}_{23}$. Untuk pernyataan $\mathrm{X}_{21}$ memiliki nilai loading 0.863 yang nilai loading-nya lebih besar dari loading ke konstruk lain yaitu 0.057, 0.047dan 0.103 dan ke 2 pernyataan dari dimensi komitmen berkelanjutan lainnya juga memiliki nilai loading yang lebih besar dari nilai loading ke konstruk lain.

Dimensi komitmen normatif yang memiliki 3 pernyataan yang dilambangkan dengan $\mathrm{X}_{31}, \mathrm{X}_{32}$, dan $\mathrm{X}_{33}$. Untuk pernyataan $\mathrm{X}_{31}$ memiliki nilai loading 0.769 yang nilai loading-nya lebih besar dari loading ke konstruk lain yaitu $-0.039,0.227 \mathrm{dan}$ 0.008dan ke 2 pernyataan dari dimensi komitmen normatif lainnya juga memiliki nilai loading yang lebih besar dari nilai loading ke konstruk lain. Variabel kepuasan kerja yang memiliki 4 indikator yang dilambangkan dengan $\mathrm{Y}_{11}, \mathrm{Y}_{12}, \mathrm{Y}_{13}$ dan $\mathrm{Y}_{14}$. Untuk pernyataan $\mathrm{Y}_{11}$ memiliki nilai loading 0.885 yang nilai loading-nya lebih besar dari loading ke konstruk lain yaitu 0.028, 0.008 dan 0.040 dan ke 2 indikator dari kepuasan kerja lainnya juga memiliki nilai loading yang lebih besar dari nilai loading ke konstruk lain.

\section{Evaluasi Model Struktural (Inner Model)}

Tahap selanjutnya adalah melakukan evaluasi struktural (inner model) yang meliputi uji kecocokan model (model fit), path coefficient, dan R2. Pada uji kecocokan model terdapat 3 indeks pengujian, yaitu average path coefficient (APC), average Rsquared (ARS) dan average varians factor (AVIF) dengan kriteria APC dan ARS diterima dengan syarat $p-$ value $<0,05$ dan AVIF $<5$ (Mahfud Sholihin dan Dwi Ratmono, 2013: 61). Berikut ini adalah hasil output model fit indices yang disajikan dalam bentuk tabel yaitu:

Berikut ini adalah hasil output model fit indices yang disajikan dalam bentuk tabel yaitu:

Tabel 4. Model fit indices

\begin{tabular}{|c|c|c|c|c|}
\hline Model 2 & Indeks & P-Value & Kriteria & Keterangan \\
\hline APC & 0.276 & $\mathrm{P}=<0.001$ & $\mathrm{P}<0,05$ & Diterima \\
\hline ARS & 0.269 & $\mathrm{P}=0.007$ & $\mathrm{P}<0,05$ & Diterima \\
\hline AVIF & 1.015 Acceptable if $<5$ & & $\mathrm{AVIF}<5$ & Diterima \\
\hline
\end{tabular}

Hasil output di atas, menjelaskan bahwa APC memiliki indeks sebesar 0.276 dengan nilai $p-$ value $<0,001$. Sedangkan ARS memiliki indeks sebesar 0.269 dengan $p$-value $<0,001$. Berdasarkan kriteria, APC sudah memenuhi kriteria karena memiliki nilai $\mathrm{p}<0,001$. Begitu pula dengan nilai $\mathrm{p}$ dari ARS yaitu $\mathrm{p}<0,001$. Nilai AVIF yang harus $<5$ sudah terpenuhi karena berdasarkan data tersebut AVIF nilainya 1,072. Dengan demikian, maka inner model dapat diterima. 


\section{JURNAL ORGANISASI DAN MANAJEMEN}

Issue 3 (November, 2017)

\section{Uji Hipotesis}

Hasil korelasi antar konstruk diukur dengan melihat path coefficients dan tingkat signifikansinya yang kemudian dibandingkan dengan hipotesis penelitian yang terdapat di bab dua. Tingkat signifikansi yang dipakai dalam penelitian ini adalah sebesar 5\%. Berikut ini hipotesis yang dimaksudkan untuk membuktikan kebenaran dugaan, yaitu:

\begin{tabular}{|l|l|}
\hline $\mathrm{H}_{1}$ & $\begin{array}{l}\text { Komitmen Organisasional pada dimensi komitmen afektif berpengaruh positif dan } \\
\text { signifikan terhadap kepuasan kerja pegawai Perusahaan Daerah Air Minum Kota } \\
\text { Makassar. }\end{array}$ \\
\hline $\mathrm{H}_{2}$ & $\begin{array}{l}\text { Komitmen Organisasional pada dimensi komitmen berkelanjutan berpengaruh positif } \\
\text { dan signifikan terhadap kepuasan kerja pegawai Perusahaan Daerah Air Minum Kota } \\
\text { Makassar }\end{array}$ \\
\hline $\mathrm{H}_{3}$ & $\begin{array}{l}\text { Komitmen Organisasional pada dimensi komitmen normatif berpengaruh positif dan } \\
\text { signifikan terhadap kepuasan kerja pegawai Perusahaan Daerah Air Minum Kota } \\
\text { Makassar. }\end{array}$ \\
\hline $\mathrm{H}_{4}$ & $\begin{array}{l}\text { Komitmen berkelanjutan merupakan variabel yang berpengaruh positif dan signifikan } \\
\text { terhadap kepuasan kerja pegawai Perusahaan Daerah Air Minum Kota Makassar }\end{array}$ \\
\hline
\end{tabular}

Berikut ini tabel hasil penelitian dari effect size yang telah diperoleh berdasarkan pengolahan data:

Tabel 5. Direct Effects

\begin{tabular}{|c|c|c|c|c|c|}
\hline Kriteria & Variabel & KA & KB & KN & KK \\
\hline \multirow[t]{4}{*}{ Path coefficients } & KA & - & - & - & - \\
\hline & KB & - & - & - & - \\
\hline & KN & - & - & - & - \\
\hline & KK & 0.166 & -0.285 & -0.378 & - \\
\hline \multirow[t]{4}{*}{$p$-values } & KA & - & - & - & - \\
\hline & KB & - & - & - & - \\
\hline & $\mathbf{K N}$ & - & - & - & - \\
\hline & KK & 0.092 & 0.010 & $<0.001$ & - \\
\hline \multirow[t]{4}{*}{ Effect size for path } & KA & - & - & - & - \\
\hline & KB & - & - & - & - \\
\hline & KN & - & - & - & - \\
\hline & KK & 0.039 & 0.081 & 0.149 & - \\
\hline
\end{tabular}

Hasil output di atas, menjelaskan bahwa path coefficients untuk variabel komitmen organisasional yang terdiri dari komitmen afektif terhadap kepuasan kerja pegawai memiliki indeks sebesar 0.166 dengan nilai $p-v a l u e<0,001$ dan nilai effect size for path0.039, komitmen berkelanjutan terhadap kepuasan kerja pegawai memiliki indeks sebesar -0.285 dengan nilai $p$-value $<0,001$ dan nilai effect size for path0.081,komitmen normatif terhadap kepuasan kerja pegawai memiliki indeks sebesar -0.378dengan nilai $p$-value $<0,001$ dan nilai effect size for path0.149.

Berikut ini merupakan gambar hasil penelitian dari effect size yang telah diperoleh berdasarkan pengolahan data:

\section{Gambar 1. Hasil penelitian}

Authors : Indriyani Tahir et al. (November, 2017). 90 - 104 


\section{JURNAL ORGANISASI DAN MANAJEMEN}

Issue 3 (November, 2017)

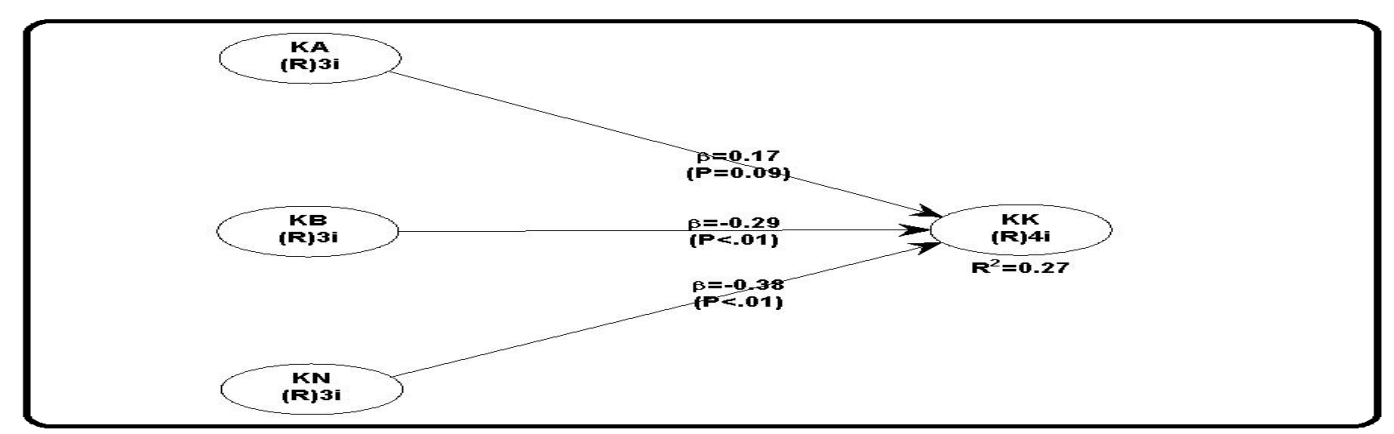

Keterangan : $\quad$ KA $\quad$ Komitmen Afektif

KB : Komitmen Berkelanjutan

KN : Komitmen Normatif

KK : Kepuasan Kerja

Berikut ini, pengujian hipotesis yang diuraikan lebih lanjut sebagai berikut:

1. Uji Hipotesis 1

a. Hipotesis

$\mathrm{H}_{1}$ : Komitmen Afektif berpengaruh positif dan tidak signifikan terhadap kepuasan kerja pegawai perusahaan daerah air minum Kota Makassar.

b. Dasar Pengambilan Keputusan $p$-value $<0,05$, maka Hipotesis diterima. $p$-value $>0,05$, maka Hipotesis ditolak.

c. Keputusan $p$-value $=0,092(<0,05)$ maka $\mathrm{H}_{1}$ ditolak.

d. Kesimpulan

Dimensi Komitmen afektif berpengaruh positif dan tidak signifikan terhadap kepuasan kerja pegawai Perusahaan Daerah Air Minum Kota Makassar. Hal tersebut menunjukkan bahwa variabel Komitmen afektif memiliki pengaruh terhadap kepuasan kerja pegawai yang dapat diamati melalui nilai koefisien jalur yang cukup besar yaitu 0.166. Angka ini menunjukkan bahwa jika terjadi peningkatan pada komitmen afektif, maka kepuasan kerja pegawai akan meningkat sebesar 0.166 dan begitu pula sebaliknya, setiap terjadi penurunan komitmen afektif, maka kepuasan kerja pegawai akan menurun sebesar 0.166 .

2. Uji Hipotesis 2

a. Hipotesis

$\mathrm{H}_{2}$ : Komitmen Berkelanjutan berpengaruh negatif dan signifikan terhadap kepuasan kerja pegawai perusahaan daerah air minum Kota Makassar Dasar Pengambilan Keputusan

$p$-value $\leq 0,05$, maka Hipotesis diterima.

$p$-value $>0,05$, maka Hipotesis ditolak.

b. Keputusan 


\section{JURNAL ORGANISASI DAN MANAJEMEN}

Issue 3 (November, 2017)

$p$-value $=0,063(\geq 0,05)$ maka $\mathrm{H}_{2}$ diterima.

c. Kesimpulan

Dimensi Komitmen berkelanjutan berpengaruh negatif dan signifikan terhadap kepuasan kerja pegawai Perusahaan Daerah Air Minum Kota Makassar. Hal tersebut menunjukkan bahwa variabel Komitmen berkelanjutan memiliki pengaruh terhadap kepuasan kerja pegawai yang dapat diamati melalui nilai koefisien jalur yang cukup besar yaitu -0.285. Angka ini menunjukkan bahwa jika terjadi peningkatan pada komitmen berkelanjutan, maka kepuasan kerja pegawai akan meningkat sebesar 0.285dan begitu pula sebaliknya, setiap terjadi penurunan komitmen berkelanjutan, maka kepuasan kerja pegawai akan menurun -0.285.

3. Uji Hipotesis 3

a. Hipotesis

$\mathrm{H}_{3}$ : Komitmen Normatif berpengaruh negatif dan signifikan terhadap kepuasan kerja pegawai perusahaan daerah air minum Kota Makassar.

Dasar Pengambilan Keputusan

$p$-value $\leq 0,05$, maka Hipotesis diterima.

$p$-value $>0,05$, maka Hipotesis ditolak.

b. Keputusan

$p$-value $=<0,001(\leq 0,05)$ maka $\mathrm{H}_{3}$ diterima.

c. Kesimpulan

Variabel Komitmen normatif berpengaruh negatif dan signifikan terhadap kepuasan kerja pegawai Perusahaan Daerah Air Minum Kota Makassar. Hal tersebut menunjukkan bahwa variabel Komitmen normatif memiliki pengaruh terhadap kepuasan kerja pegawai yang dapat diamati melalui nilai koefisien jalur yang cukup besar yaitu -0.378. Angka ini menunjukkan bahwa jika terjadi peningkatan pada komitmen normatif, maka kepuasan kerja pegawai akan meningkat sebesar -0.378dan begitu pula sebaliknya, setiap terjadi penurunan komitmen normatif, maka kepuasan kerja pegawai akan menurun -0.378.

4. Uji Hipotesis 4

a. Hipotesis

$\mathrm{H}_{3}$ : Komitmen afektif dominan berpengaruh positif dan tidak signifikan terhadap kepuasan kerja Perusahaan Daerah Air Minum Kota Makassar.

Dasar Pengambilan Keputusan

$p$-value $\leq 0,05$, maka Hipotesis diterima.

$p$-value $>0,05$, maka Hipotesis ditolak.

b. Keputusan

$p$-value $=<0,001(\leq 0,05)$ maka $\mathrm{H}_{3}$ ditolak.

c. Kesimpulan 


\section{JURNAL ORGANISASI DAN MANAJEMEN}

Issue 3 (November, 2017)

Dimensi komitmen afektif dominan berpengaruh terhadap kepuasan kerja pegawai Perusahaan Daerah Air Minum Kota Makassar. Hal tersebut menunjukkan bahwa dimensi komitmen afektif memiliki pengaruh yang tinggi terhadap kepuasan kerja pegawai yang dapat diamati melalui nilai koefisien jalur yaitu 0.166 dibandingkan dimensi komitmen berkelanjutan yang memiliki pengaruh terhadap kepuasan kerja pegawai dengan nilai koefisien jalur yaitu -0.378. Angka ini menunjukkan bahwa jika nilai koefisien jalur dimensi komitmen afektif lebih tinggi dibandingkan dimensi komitmen berkelanjutan.

Setelah melakukan uji hipotesis di atas, berikut ini tabel yang merangkum uji hipotesis-hipotesis tersebut :

Tabel 6. Hasil uji hipotesis

\begin{tabular}{|c|c|c|c|c|}
\hline Hipotesis & Independen & Dependen & p-values & Keputusan \\
\hline $\mathrm{H}_{1}$ & Kepuasan Kerja & Komitmen Afektiv & 0.092 & Ditolak \\
\hline $\mathrm{H}_{2}$ & Kepuasan Kerja & Komitmen & 0.010 & Ditolak \\
& Kepuasan Kerja & Komitmen Normatif & $<0.001$ & Ditolak \\
\hline $\mathrm{H}_{3}$ & Kepuasan Kerja & Dominan Komitmen & Nilai -0.166> \\
dari nilai - & Ditolak \\
& & & 0.378 dan - \\
& & & 0.285 & \\
& & & & \\
& & & & \\
& & &
\end{tabular}

Berdasarkan tabel hasil uji hipotesis di atas, dapat diperoleh:

1) Uji hipotesis 1 diterima, artinya variabel karakteristik individu memiliki pengaruh positif dan signifikan terhadap kinerja pegawai pada KPP Pratama Makassar Utara. Hal ini ditunjukkan dengan nilai beta $(\beta)$ sebesar 0,701 dengan nilai $p$-value $<0.001$.

2) Uji hipotesis 2 ditolak, artinya variabel pemanfaatan teknologi informasi memiliki pengaruh positif dan tidak signifikan terhadap kinerja pegawai pada KPP Pratama Makassar Utara. Hal ini ditunjukkan dengan nilai beta ( $\beta$ ) sebesar 0,157 dengan nilai $p$-value 0,063 .

3) Uji hipotesis 3 diterima, artinya variabel karakteristik individu dominan memiliki pengaruh positif dan signifikan terhadap kinerja pegawai pada KPP Pratama Makassar Utara. Hal ini ditunjukkan dengan variabel karakteristik individu memiliki nilai lebih tinggi yaitu nilai beta $(\beta)$ sebesar 0,701 dengan nilai $p$-value $<0.001$ dibandingkan dengan variabel pemanfaatan teknologi informasi dengan nilai beta $(\beta)$ sebesar 0,157 dan nilai $p$-value 0,063 .

4) Uji hipotesis 4 diterima, artinya variabel karakteristik individu dominan memiliki pengaruh positif dan signifikan terhadap kinerja pegawai pada KPP Pratama Makassar Utara. Hal ini ditunjukkan dengan variabel karakteristik individu memiliki nilai lebih tinggi yaitu nilai beta $(\beta)$ sebesar 0,701 dengan nilai $p$-value $<0.001$ dibandingkan dengan variabel pemanfaatan teknologi informasi dengan nilai beta $(\beta)$ sebesar 0,157 dan nilai $p$-value 0,063.

\section{a. Uji besaran pengaruh variabel independen terhadap variabel dependen}


Issue 3 (November, 2017)

Pengujian besaran pengaruh variabel independen terhadap variabel dependen dapat ditunjukkan pada tabel berikut:

Tabel 7. Ringkasan model (model summary)

\begin{tabular}{|c|c|c|c|c|}
\hline Pengukuran & KA & KB & KN & KK \\
\hline R-squared & & & & 0.269 \\
\hline Adj. R-squared & & & & 0.228 \\
\hline Composite reliab. & 0.835 & 0.902 & 0.892 & 0.937 \\
\hline Cronbach's Alpha & 0.699 & 0.836 & 0.816 & 0.909 \\
\hline Avg. Var. Extrac. & 0.630 & 0.755 & 0.735 & 0.787 \\
\hline
\end{tabular}

Berdasarkan tabel diatas besaran pengaruh nilai $R$-squared pada variabel komitmen organisasional terhadap kepuasan kerja pegawai adalah 0.269 (26,0\%) dan sisanya $73,0 \%$ dipengaruhi oleh variabel lain yang tidak dianalisis dalam penelitian ini seperti motivasi kerja, disiplin kerja, dan variabel lainnya.

\section{a. Pengaruh Dimensi Komitmen Afektive Terhadap Kepuasan Kerja}

Berdasarkan hasil penelitian, ditemukan bahwa komitmen afektiv memiliki pengaruh terhadap kepuasan kerja. Hasil ini sama dengan teori atau temuan dalam penelitian sebelumnya oleh Pramitha, (2012) memberikan bukti bahwa komitmen afektif sebahagian mendukung kepuasan kerja pegawai. Dalam penelitian ini dapat dilihat dari nilai koefisien beta yang menunjukkan bahwa komitmen afektiv memiliki pengaruh negatifdan tidak signifikan terhadap kepuasan kerja yaitu dengan nilai beta $(\beta)$ sebesar 0.166. Hal ini menunjukkan bahwa variabel komitmen afektif dapat memengaruhi peningkatan kepuasan kerja. Penyebab negatif dan tidak signifikannya pengaruh komitmen afektiv terhadap kepuasan kerjadiakibatkan karena pegawai merasa bahagia menghabiskan sisa karir, merasa menjadi keluarga dan apapun masalah yang ada di perusahaan menjadi tanggung jawab pegawai Perusahaan Daerah Air Minum Kota Makassar. Kondisi tersebut didukung dengan kepuasan pekerja itu sendiri dikarenakan pegawai dapat menyelesaikan pekerjaanya walaupun pekerjaan menantang dalam pekerjaan memiliki pekerjaan yang beragam dan bertanggung jawab atas seluruh pekerjaan yang diberikan kepada pimpinan Perusahaan Daerah Air Minum Kota Makassar.

\section{b. Pengaruh Komitmen Berkelanjutan Terhadap Kepuasan Kerja Pegawai}

Berdasarkan hasil penelitian, ditemukan bahwa komitmen berkelanjutan memiliki pengaruh terhadap kepuasan kerja pegawai. Hasil ini sama dengan teori atau temuan dalam penelitian sebelumnya oleh Pramitha, (2012) bahwa komitmen berkelanjutan berpengaruh negatif dan signifikan terhadap Kepuasan kerja pegawai. Dalam penelitian ini dapat dilihat dari nilai koefisien beta yang menunjukkan bahwa komitmen berkelanjutan memiliki pengaruh negatifdan signifikan terhadap kepuasan kerja pegawai yaitu dengan nilai beta $(\beta)$ sebesar -0.285 . Hal ini menunjukkan bahwa dimensi komitmen berkelanjutan terhadap pegawai jika

Authors : Indriyani Tahir et al. (November, 2017). 90 - 104

Halaman 101 


\section{JURNAL ORGANISASI DAN MANAJEMEN}

Issue 3 (November, 2017)

meninggalkan perusahaan akan merasa rugi sehingga sulit untuk mendapatkan pekerjaan dengan penghasilan yang bagus dan pegawai sulit meninggalkan perusahaan karena takut tidak mendapatkan kesempatan kerja ditempat lain. Kondisi tersebut didukung dengan kepuasan dengan rekan kerja dikarenakan permasalahan yang ada di perusahaan dapat terselesaikan dengan bantuan rekan kerja untuk tidak terlibat dalam konflik dengan rekan kerja dan memiliki kemampuan untuk bekerja sama dengan siapa pun di Perusahaan Daerah Air Minum Kota Makassar.

\section{c. Pengaruh Komitmen Normatif Terhadap Kepuasan Kerja Pegawai}

Berdasarkan hasil penelitian, ditemukan bahwa komitmen normatif memiliki pengaruh terhadap kepuasan kerja pegawai. Hasil ini sama dengan teori atau temuan dalam penelitian sebelumnya oleh Pramitha, (2012) bahwa komitmen normatif berpengaruh negatif dan signifikan terhadap Kepuasan kerja pegawai. Dalam penelitian ini dapat dilihat dari nilai koefisien beta yang menunjukkan bahwa komitmen berkelanjutan memiliki pengaruh negatifdan signifikan terhadap kepuasan kerja pegawai yaitu dengan nilai beta $(\beta)$ sebesar -0.378. Hal ini menunjukkan bahwa dimensi komitmen normatif belum mampu memengaruhi peningkatan kepuasan kerja pegawai. Penyebab negatif dan signifikannya pengaruh komitmen berkelanjutan terdapat kepuasan kerja kinerja pegawai diakibatkan karena pegawai mesaya layak memberikan kesetiaan kepada perusahaan karena perusahaan ini banyak berjasa dan pegawai belum memberikan banyak kontribusi bagi Perusahaan Daerah Air Minum Kota Makassar. Kondisi tersebut didukung dengan kepuasan rekan kerja karena permasalahan yang saya hadapi dapat terselesaikan dengan adanya dukungan rekan kerja memiliki kemampuan untuk berkerjasama dengan siapapun dan pegawai tidak terlibat konflik dengan rekan kerja di Perusahaan Daerah Air Minum Kota Makassar.

\section{d. Pengaruh Komitmen Afektif Dominan Terhadap Kepuasan Kerja Pegawai}

Berdasarkan hasil penelitian, ditemukan bahwa pengaruh komitmen normatif lebih dominan dibandingkan pengaruh pemanfaatan teknologi informasi terhadap kinerja pegawai. Hasil tersebut dalam penelitian ini dapat dilihat dari nilai koefisien beta yang ditunjukkan komitmen afektiflebih tinggi yaitu dengan nilai beta ( $\beta$ ) sebesar0.166 dan nilai koefisien beta yang ditunjukkan oleh komitmen berkelanjutan yaitu dengan nilai $-0,285$. Hal ini menunjukkan bahwa dimensi komitmen afektif dapat memengaruhi peningkatan kepuasan kerja pegawai kearah yang lebih tinggi dibandingkan dimensi komitmen berkelanjutan. Penyebab positif dan tidak signifikannya dominan pengaruh komitmen afektif terhadap kepuasan kerja pegawaiHal ini menunjukkan bahwa variabel komitmen afektif dapat memengaruhi peningkatan kepuasan kerja. Penyebab negatif dan tidak signifikannya pengaruh komitmen afektiv terhadap kepuasan kerjadiakibatkan karena pegawai merasa bahagia menghabiskan sisa karir, merasa menjadi keluarga 


\section{JURNAL ORGANISASI DAN MANAJEMEN}

Issue 3 (November, 2017)

dan apapun masalah yang ada di perusahaan menjadi tanggung jawab pegawai Perusahaan Daerah Air Minum Kota Makassar. Kondisi tersebut didukung dengan kepuasan pekerja itu sendiri dikarenakan pegawai dapat menyelesaikan pekerjaanya walaupun pekerjaan menantang dalam pekerjaan memiliki pekerjaan yang beragam dan bertanggung jawab atas seluruh pekerjaan yang diberikan kepada pimpinan Perusahaan Daerah Air Minum Kota Makassar.

\section{Kesimpulan}

Berdasarkan hasil pengujian dan pembahasan sebagaimana telah disajikan, maka dapat ditarik kesimpulan sebagai berikut:

1. Komitmen Afektif berpengaruh positif dan tidak signifikan terhadap kepuasan kerja Pegawai Perusahaan Daerah Air Minum Kota Makassar. Kondisi tersebut disebabkan karena pegawai merasa bahagia menghabiskan sisa karir, merasa menjadi keluarga dan apapun masalah yang ada di perusahaan menjadi tanggung jawab pegawai Perusahaan Daerah Air Minum Kota Makassar. Kondisi tersebut didukung dengan kepuasan pekerja itu sendiri dikarenakan pegawai dapat menyelesaikan pekerjaanya walaupun pekerjaan menantang dalam pekerjaan memiliki pekerjaan yang beragam dan bertanggung jawab atas seluruh pekerjaan yang diberikan kepada pimpinan Perusahaan Daerah Air Minum Kota Makassar.

2. Komitmen Berkelanjutan berpengaruh negatif dan signifikan terhadap kepuasan kerja Pegawai Perusahaan Daerah Air Minum Kota Makassar. Kondisi tersebut disebabkan karena pegawai jika meninggalkan perusahaan akan merasa rugi sehingga sulit untuk mendapatkan pekerjaan dengan penghasilan yang bagus dan pegawai sulit meninggalkan perusahaan karena takut tidak mendapatkan kesempatan kerja ditempat lain. Kondisi tersebut didukung dengan kepuasan dengan rekan kerja dikarenakan permasalahan yang ada di perusahaan dapat terselesaikan dengan bantuan rekan kerja untuk tidak terlibat dalam konflik dengan rekan kerja dan memiliki kemampuan untuk bekerja sama dengan siapa pun di Perusahaan Daerah Air Minum Kota Makassar.

3. Komitmen Normatif berpengaruh negatif dan signifikan terhadap kepuasan kerja Pegawai Perusahaan Daerah Air Minum Kota Makassar. Kondisi tersebut disebabkan karenapegawai mesaya layak memberikan kesetiaan kepada perusahaan karena perusahaan ini banyak berjasa dan pegawai belum memberikan banyak kontribusi bagi Perusahaan Daerah Air Minum Kota Makassar. Kondisi tersebut didukung dengan kepuasan rekan kerja karena permasalahan yang saya hadapi dapat terselesaikan dengan adanya dukungan rekan kerja memiliki kemampuan untuk berkerjasama dengan siapapun dan pegawai tidak terlibat konflik dengan rekan kerja di Perusahaan Daerah Air Minum Kota Makassar. 


\section{JURNAL ORGANISASI DAN MANAJEMEN}

Issue 3 (November, 2017)

\section{DAFTAR PUSTAKA}

Arikunto, S. (2002). Metodologi penelitian. Jakarta: PT. Rineka Cipta.

Chandraningtyas, I., Al Musadieq, M., \& Utami, H. N. (2012). Pengaruh kepuasan kerja dan motivasi kerja terhadap kinerja karyawan melalui komitmen organisasional (studi pada karyawan PT. Kusuma Karya Persada yang outsourcing di PT. Sasa Inti Probolinggo). PROFIT (JURNAL ADMINISTRASI BISNIS), 6(2).

Ferdinand, A. (2006). Metode Penelitian Manajemen: Pedoman Penelitian untuk Penulisan Skripsi, Tesis, dan Disertasi Ilmu Manajemen. Semarang: Badan Penerbit Universitas Diponegoro

Kristanto, S., Rahyuda, I. K., \& Riana, I. G. (2013). Pengaruh keadilan organisasional terhadap kepuasan kerja dan dampaknya terhadap komitmen, dan intensi keluar di pt indonesia power ubp bali. E-Jurnal Ekonomi dan Bisnis Universitas Udayana, 3(06).

Noor, Z. A. (2012). Pengaruh Budaya Organisasi, Komitmen Organisasi, dan Motivasi Kerja terhadap Kepuasan Kerja dan Kinerja Karyawan. EKUITAS (Jurnal Ekonomi dan Keuangan), 16(4), 473-486.

Pamungkas, M. A., \& Rahardjo, M. (2014). Analisis pengaruh kepuasan kerja dan komitmen organisasi terhadap kinerja karyawan (Studi Pada Perusahaan Daerah Air Minum Kota Cirebon)(Doctoral dissertation, Fakultas Ekonomika dan Bisnis).

Puspitawati, N. M. D., \& Riana, I. G. (2014). Pengaruh kepuasan kerja terhadap komitmen Organisasional dan kualitas layanan. Jurnal Manajemen Strategi Bisnis dan Kewirausahaan, 8(1).

Rimata Ega Praja, E. (2014). Pengaruh komitmen organisasi dan motivasi kerja terhadap kepuasan kerja karyawan pt. Pos indonesia yogyakarta (doctoral dissertation, fakultas ekonomi).

Sjahruddin, H. (2016). Pengaruh motivasi intrinsik dan ekstrinsik terhadap kinerja Aparatur Sipil Negara (ASN) pada Badan Pusat Statistik. Jurnal 1 E-Library STIE YPBUP Bongaya.

Sjahruddin, H., \& Sudiro, A. A. (2013). Organizational justice, organizational commitment and trust in manager as predictor of organizational citizenship behavior. Interdiciplinary J. of contemporary Res. Bus.(IJCRB), 4(12), 133-141.

Sutrisno, E. (2009). Pengertian Manajemen sumber daya manusia.Sofyan, Y., \& Heri, K. (2009). SPSS Complete. Teknik Analisis Statistik Terlengkap dengan Software SPSS, Aplikasi statistik, Salemba Infotek, Jakarta.

Tranggono, R. P., \& Kartika, A. (2008). Pengaruh Komitmen Organisasional dan Profesional Terhadap Kepuasan Kerja Auditor Dengan Motivasi Sebagai Variabel Intervening (Studi Empiris pada Kantor Akuntan Publik di Semarang). Jurnal Bisnis dan Ekonomi, 15(1).

Wibowo, I., \& Putro, G. (2015). Pengaruh Stres Kerja Terhadap Kepuasan Kerja dan Komitmen Organisasional Karyawan UD Ulam Sari Denpasar (Doctoral dissertation, Tesis. Universitas Udayana. Online, www. PPs. unud. ac. id/thesis/pdf_thesis diakses pada 25 Nopember).

Wijaya, I. M. B. G., \& Suana, I. W. (2013). Pengaruh Penempatan Dan Pengalaman Terhadap Kepuasan Dan Kinerja Karyawan. E-Jurnal Manajemen Universitas Udayana, 2(10). 